Poznań

\title{
Prasa polska o wyborach do Parlamentu Europejskiego w 2009 roku
}

7 czerwca 2009 roku po raz drugi odbyły się w Polsce wybory do Parlamentu Europejskiego. Głosami 24,5\% społeczeństwa zwyciężyła Platforma Obywatelska uzyskując 44,43\% głosów poparcia. Drugie miejsce zajęła partia Prawo i Sprawiedliwość otrzymując 27,4\% głosów, trzecie sojusz SLD-UP 12,34\%, a czwarte PSL 7,01\%. Progu wyborczego (5\%) nie przekroczyły ugrupowania: Unia Polityki Realnej 1,10\% głosów, Samoobrona 1,46\%, Polska Partia Pracy 0,70\%, Libertas 1,14\%, Centrolewica 2,44\%, Prawica Rzeczpospolitej 1,95\%, Polska Partia Socjalistyczna $0,02 \%$ oraz Naprzód Polsko $0,02 \%$ głosów poparcia ${ }^{1}$.

Wyniki do Parlamentu Europejskiego potwierdziły wcześniejsze obawy związane z małym na skalę kraju poparciem społecznym dla demokratycznej instytucji wyborów powszechnych. Społeczeństwo polskie po raz kolejny dało władzy wyraźny sygnał braku zainteresowania sprawami publicznymi. Podczas kampanii wyborczej bardziej interesowało się sprawami krajowymi, aniżeli europejskimi, nie bez winy polityków utożsamiało wybory do Parlamentu Europejskiego z krajowymi. Natomiast dla ugrupowań politycznych nastroje społeczne były wymiernym wskaźnikiem poparcia i sugestią, jaką taktykę należy obrać przed zbliżającymi się wyborami prezydenckimi, a następnie samorządowymi. Podobnie jak w poprzednich Eurowyborach, w trakcie kampanii zabrakło merytorycznej dyskusji m.in., na temat kompetencji Europarlamentu oraz rosnącego znaczenia tej instytucji w strukturze Unii Europejskiej. Za mało zaangażowano również sił i środków, aby zmobilizować elektorat do głosowania i móc w końcu w pełni korzystać z praw członka Unii Europejskiej.

\section{Przed wyborami}

Kampania wyborcza do Parlamentu Europejskiego rozpoczęła się w drugiej połowie maja 2009 roku. Początkowo w prasie polskiej pojawiło się niewiele informacji na temat sylwetek kandydatów do Europarlamentu i ich poglądów. W miarę zbliżania się terminu głosowania, wybory do Parlamentu Europejskiego wzbudzały większe zainteresowanie massmediów. Coraz częściej dyskutowano na temat kwalifikacji i predyspozycji kandydatów. Biorąc pod uwagę małe zaangażowanie społeczeństwa w poprzednie Eurowybory, zastanawiano się również jak zachęcić polski elektorat do uczestnictwa w wyborach.

\footnotetext{
1 Zob. szerzej, www.eurowybory-2009.org.pl.
} 
31 maja, na łamach „Myśli Polskiej” - czasopisma sympatyzującego z prawą częścią polskiej sceny politycznej zwrócono uwagę, że Eurowybory w kraju cieszą się małym zainteresowaniem społeczeństwa. Podkreślono, że podobne problemy mają inne kraje UE, szczególnie z Europy Środkowo-Wschodniej. Publicystę tygodnika, Zbigniewa Lipińskiego nie dziwiła ta sytuacja. Jego zdaniem eurodeputowani w Strasburgu nic ważnego nie są w stanie załatwić dla swoich krajów, stąd niewielka liczba elektoratu chce dać im mandat wyborczy: „... O ile kilku kandydatów mających na względzie dobro Polski wejdzie do Parlamentu Europejskiego, to z powodu struktury i kompetencji (a właściwie braku kompetencji) nic lub niewiele dla Polski będą w stanie uczynić" . W dalszej części artykułu Lipiński nazwał kampanię wyborczą błazenadą, a pojawienie się na scenie politycznej ugrupowania „Libertas” powiązał z próbą reaktywacji Ligi Polskich Rodzin i potrzebą odrodzenia się jej członków: ,,interes polityczny, pomijając finansowy, zrobi na «Libertasie» przede wszystkim LPR. Inicjatywa irlandzkiego milionera dała Giertychowi okazję na wydobycie LPR z niebytu, bo W obecnym stanie nie stać jej na rejestrację samodzielnej listy. «A po tym manewrze część ośrodków badania opinii publicznej dawało Lidze nawet 5\% poparcia»"”3. Na koniec artykułu publicysta zauważył, że wspólnym mianownikiem działalności wszystkich polskich prawicowych ugrupowań (m.in., Libertas, Prawica RP, UPR) jest krytyka Traktatu lizbońskiego.

W ostatni weekend maja, sprzyjająca polskiej lewicy „Trybuna”, opublikowała wypowiedź przewodniczącego SLD - Grzegorza Napieralskiego otwarcie krytykującego Mariana Krzaklewskiego, który zdecydował się startować w Eurowyborach z list Platformy Obywatelskiej: „Właśnie dzięki Marianowi Krzaklewskiemu doprowadzono kraj na skraj bankructwa" ", zasugerował szef SLD. Napieralski obarczył winą byłego przewodniczącego AWS za nieudolne reformy z lat dziewięćdziesiątych i nazwał go „politycznym szkodnikiem”.

24 maja w ,Zielonym Sztandarze”, organie prasowym Polskiego Stronnictwa Ludowego pojawiła się rozmowa z kandydatem do Europarlamentu Eugeniuszem Kłopotkiem. Jeden z najbardziej rozpoznawanych polityków PSL zauważył, że jego ugrupowaniu szczególnie zależy, aby w Europejskiej Partii Ludowej zasiadła silna polska reprezentacja: „Musimy pokazywać, że zgromadzenie, które ma wpływ na wydatkowanie unijnych pieniędzy decyduje o dochodach każdego polskiego rolnika. Lwią część unijnego budżetu stanowią wydatki na wspólną politykę rolną... Znaczący politycy w Europie chcą ograniczyć wydatki dla wsi i rolnictwa... Z budżetu unijnego na wieś trafiło 72 miliardy złotych. Tyle można wygrać i tyle można przegrać”. ${ }^{\text {. Na koniec }}$ rozmowy Kłopotek zasugerował, że wierzy iż PSL wyborach przekroczy $10 \%$.

20 maja we Włoszczowie, w ramach kampanii do Europarlamentu odbyło się spotkanie kandydata Prawa i Sprawiedliwości Zbigniewa Ziobro z PiS-owskim elektoratem. Redagowany przez Jerzego Urbana dziennik cotygodniowy „NIE” w charakterystycz-

2 Z. Lipiński, Wyścig do brukselskiej kasy, „Myśl Polska”, 31 maja 2009, s. 4.

3 Ibidem.

4 Przed wyborami do Parlamentu Europejskiego, „Trybuna”, 30-31 maja 2009, s. 4.

5 Ordynacja jest niekorzystna dla małych okręgów, rozmowa z Eugeniuszem Kłopotkiem, „Zielony Sztandar", 24 maja 2009, s. 3. 
ny dla siebie sposób zrelacjonował przebieg spotkania. Jeden z dziennikarzy, Maciej Wiśniowski w prześmiewczej formie starał się oddać atmosferę wizyty. Autor porównał meeting do koncertu, na podstawie którego można by nagrać płytę długogrającą. Do najważniejszych „utworów” zaliczył: „rząd nic nie robi”, „chodźmy na wybory, bo inaczej tamci nas zniszczą”, „15 miesięcy do bani, bo to my nie rządzimy”. Zdaniem Wiśniowskiego, w atmosferze nadchodzących wyborów szczególnie dobrze brzmiały piosenki: „Europa to ściema, przede wszystkim Polska i Polacy” oraz „Najpierw jest się Polakiem, a dopiero później Europejczykiem”“. Publicysta „NIE” podkreślił, że show, który dała „gwiazda” wieczoru (Zbigniew Ziobro) był możliwy dzięki wsparciu innego polityka PiS-u Edgara Gosiewskiego.

Ryszard Czarnecki na łamach tygodnika „Gazeta Polska”, przestrzegał, aby podczas kampanii wyborczej do Europarlementu prawa strona polskiej sceny politycznej nie popełniła podobnego błędu jak prawica hiszpańska, która miast podbijać serca społeczeństwa i walczyć konsekwentnie o elektorat oddawała powoli przyczółki, aż w końcu oddała całą władzę w kraju socjalistom: „płynie z tego dobra lekcja dla Polski i Polaków... próby zagarnięcia kolejnych pól życia społecznego muszą napotkać na zdecydowany opór ze strony prawicowych elit intelektualnych i politycznych. «Staropolska zasada jakoś tam będzie nie może mieć zastosowania»" "7.

W tym samym numerze tygodnika pojawiła się rozmowa z kandydatem PiS-u do Parlamentu Europejskiego - Michałem Kamińskim. Publicysta tygodnika, Filip Rdesiński zapytał prezydenckiego ministra o to, co zaoferuje społeczeństwu rodząca się nowa formacja w Strasburgu. Eurodeputowany poprzedniej kadencji zasugerował, że tak jak czescy konserwatyści i brytyjscy torysi chciałby Europy nie biurokratycznej, szanującej tradycję: „,chcemy dopełnienia integracji europejskiej w wymiarze wolnego rynku, a pragniemy hamować ją w polityce. Polska potrzebuje otwartych rynków europejskich"».

1 czerwca „Trybuna” opublikowała wywiad z liderem lewicy w pomorskim okręgu - prof. Longinem Pastusiakiem. Znawca problematyki międzynarodowej starał się przekonać do siebie wyborców głosząc konstruktywny program wyborczy, wrażliwy na troski i żale społeczne. „Człowiek pracy nie obroni się w demokracji, jeżeli nie będzie miał właściwej reprezentacji lewicowej w organach władzy ustawodawczej i wykonawczej - sugerował". Zdaniem Pastusiaka tocząca się kampania wyborcza, a szczególnie postawa partii prawicowych spycha na margines ugrupowania lewicowe, a w Europarlamencie nie da się wypracować konstruktywnych decyzji bez zaangażowania Partii Europejskich Socjalistów. „Parlament kontroluje władzę wykonawczą w Unii. A więc zmniejsza deficyt demokracji w UE. A polega on na tym, że władza wykonawcza w UE ma większy zakres władzy niż organy pochodzące z wyborów"10.

6 M. Wiśniowski, Gosiu Ziobrze robi dobrze, „Nie”, 28 maja 2009, s. 2.

7 R. Czarnecki, Zapatero przy ścianie, „Gazeta Polska”, 27 maja 2009, s. 5.

8 Rozmowa z Michatem Kamińskim, „Gazeta Polska”, 27 maja 2009, s. 7.

9 Wstuchać się w opinie ludzi, rozmowa z Longinem Pastusiakiem liderem okręu pomorskiego listy SLD-UP, „Trybuna”, 1 czerwca 2009, s. 6.

10 Ibidem. 
Jeszcze przed wyborami znani publicyści prasy polskiej zapowiadali niską frekwencję wyborczą. Sceptycznie odnosili również się do prezentowanych przez partie polityczne haseł wyborczych, które zamiast zainspirować społeczeństwo do uczestnictwa w wyborach wręcz odwrotnie, zniechęcały elektorat do aktywnego uczestnictwa.

Adam Szostkiewicz na łamach „Polityki” skrytykował lansowane przez partie polityczne hasła przewodnie kampanii do Europarlamentu: PO „Postaw na Polskę”, PiS-u „Więcej dla Polski”, centrolewicy „Europa to ludzie”, prawicy „Europa normalnych ludzi”, czy ludowców „Sukces Europy sukcesem Polski”. Znany publicysta sugerował, że prezentowane hasła mają mały związek z europejskimi wyborami. „Nie wystarczy recytować o Polsce, o obronie polskich interesów, bo to brzmi tak jakby Europa była nam obojętna lub jakbyśmy nie wierzyli, że Europa ma przyszłość ${ }^{11}$ - pisał jeszcze pod koniec maja.

Andrzej Stankiewicz na łamach „Newsweek - Polska” podzielił polskich kandydatów na „pierwszoligowców” i drugoligowców, skompromitowanych na krajowym podwórku lub odchodzących na emeryturę graczy, co najwyżej klasy okręgowej. Dokonał również analizy pobudek, jakimi kierują się kandydaci do foteli w Strasburgu. Wśród najważniejszych wymienił: „poczekanie nas lepsze czasy, wygodną emeryturę, rozgrzewkę przed przyszłorocznymi wyborami samorządowymi, motywy finansowe"12.

W dalszej części artykułu zasugerował wyborcom, aby przed dokonaniem wyboru przeanalizowali sylwetki kandydatów: ,nie wolno w ciemno głosować na listach, bo to pułapka, w którą chcą nas wciągnąć partyjni liderzy. Lepiej postawić na jego kolegę - specjalistę bez przywódczych ambicji, za to z talentem, który może się sprawdzić w Brukseli",13.

Brytyjski felietonista Edward Lucas - korespondent „The Economist”, a na co dzień dziennikarz tygodnika „Wprost”, podjął się oceny kandydatów pod kątem znajomości języka angielskiego. Na jego zaproszenie do debaty odpowiedzieli nieliczni. W doborowym gronie znaleźli się Danuta Hübner, Dariusz Rosati, Michał Kamiński, Artur Zawisza, Bogusław Liberadzki. Według Lucasa cała piątka poradziłaby sobie z pytaniami stawianymi w tym języku przez dziennikarzy. Jednak najlepiej wypadłaby komisarz Hübner. „Odnosiłem wrażenie, że w przeciwieństwie do pozostałych uczestników debaty przez cały czas myślała po angielsku. U niej myśli automatycznie zmieniały się w słowa, czego nie było widać u żadnego z pozostałych uczestników. Znam już przyczyny tej wielkiej skuteczności w brukselskiej administracji. Wyczucie niuansów i umiejętność wyboru odpowiedniego momentu zapewniały jej szczególną sprawność w zakulisowej dyplomacji Parlamentu Europejskiego"14.

Na kilka dni przed wyborami znana publicystka „Polityki”, Janina Paradowska określiła kampanię wyborczą jako nudną: „,pozbawioną z reguły ostrych spięć, całej tej dekoracyjnej krajowej pyskówki" ${ }^{\prime 15}$. Zauważyła również, że zaangażowanie społeczeństwa w debatę jest odwrotnie proporcjonalne do zaangażowania polityków, szczególnie

11 A. Szostkiewicz, Tak, ale nie, „Polityka”, 30 maja 2009, s. 16.

12 A. Stankiewicz, Mecz na wyjeździe, „Newsweek - Polska”, 31 maja 2009, s. 25.

13 Ibidem, s. 26.

14 E. Lucas, Mówicie po angielsku lepiej niż ja po polsku, „Wprost”, 7 czerwca 2009, s. 63.

15 J. Poaradowska, Nastrój siadt, „Polityka”, 6 czerwca 2009, s. 17. 
pod koniec kampanii: „Im większa desperacja czy wręcz żarliwość polityków w szukaniu efektownych rzutów na taśmę, by poprawić wynik, tym większa dezorientacja lub brak zainteresowania wyborców"16. Zdaniem Paradowskiej oparciem dla kampanii była głównie niepewna sytuacja gospodarcza.

W tym samym numerze „Polityki” inny publicysta tygodnika Marek Ostrowski mobilizował społeczeństwo do uczestnictwa w wyborach, aby nie powtórzyć słabego wyniku z 2004 roku, kiedy tylko 20,87\% wyborców poszło do urn, a w całej Europie gorszy wynik odnotowano tylko na Słowacji (udział 16\% wyborców). Ostrowski podkreślił, że „Parlament - mimo swych słabości i ograniczonych kompetencji - stoi na straży wspólnoty, jest czynnikiem łączącym Unię, próbuje łagodzić egoizmy narodowe. Słabszemu krajowi, takiemu jak Polska jest bardzo potrzebny"17.

Brak autentycznej kampanii wyborczej podczas wyborów do Parlamentu Europejskiego, podkreślały w tym czasie czołowe czasopisma w Polsce. Wśród głównych zarzutów kierowanych w stronę komitetów wyborczych partii politycznych pojawiły się: mało przekonujące zaangażowanie partii w mobilizowanie elektoratu, traktowanie wyborów do Europarlamentu jako preludium kampanii do przyszłych wyborów prezydenckich i parlamentarnych w kraju, co wiązało się z kolei z minimalnym wkładem finansowym ugrupowań politycznych w Eurowybory.

Na łamach „Rzeczpospolitej”, Bronisław Wildstein z dużym przekonaniem sugerował, że przeciętny obywatel Polski nie wie czym jest Europarlament i jakie posiada kompetencje. Podkreślił, że główną cechą Europarlamentu - podobnie jak innych instytucji unijnych - jest nieokreśloność. Sugerował, że wraz z kolejnymi traktatami europejskimi zmieniał się charakter i funkcje instytucji unijnych. Sytuacja ta przyczyniła się do braku zrozumienia ich przeznaczenia i wprowadziła chaos: „... to sprawia, że Parlament Europejski stanowi spektakl pozorów, określający byt instytucji, która choć nazywa się Parlamentem, nim nie jest. Nic więc dziwnego, że wybory do niego traktowane są we wszystkich krajach Unii, jako przygrywka do wyborów krajowych. Nikt, łącznie z samymi kandydatami, nie traktuje specjalnie poważnie ich unijnych deklaracji, a wyborcy nie za bardzo mają możliwość sprawdzenia aktywności swoich przedstawicieli w PE i nie za bardzo ona ich interesuje" ${ }^{, 18}$.

Według publicysty „Rzeczpospolitej” Europarlament jawił się jako „klub towarzyski, którego większość członków ma poczucie misji przekształcenia Europy"19.

Joanna Kowalska-Iszkowska na łamach „Newsweek - Polska” starała się wyważyć głosy euroentuzjastów i eurosceptyków. Biorąc pod uwagę kryterium mobilizacji, podzieliła kandydatów do foteli w Strasburgu na aktywnych i leniwych. Postulowała uczestnictwo w wyborach, gdyż jej zdaniem był to jedyny sposób, aby zwykły obywatel mógł na unię wpłynąć. Zachęcając do wyborów sporządziła listę zasług pracowitych eurodeputowanych, wśród których wymieniła „zmniejszenie stawek za roaming komórkowy, podawanie przez linie lotnicze rzeczywistej ceny biletów, odszkodowania dla podróżnych za opóźnienie pociągów, odejście od instalowania na lotniskach skane-

16 Ibidem.

17 M. Ostrowski, Jedyny show w mieście, „Polityka”, 6 czerwca 2009, s. 21.

18 B. Wildstein, Europejski spektakl pozorów, „Rzeczpospolita”, 2 czerwca 2009, s. 14.

19 Ibidem. 
rów, które bez konieczności zdejmowania ubrania pozwalają uzyskać obraz ludzkiego ciała ze szczegółami anatomicznymi”,20.

Z drugiej strony zauważyła, że wśród europosłów są też tacy, którzy przyjeżdżają do Strasburga, aby podpisać listę obecności i pobrać dochody sięgające około 12 tys. euro miesięcznie. Do tej grupy zaliczyła grono zwolenników Romana Giertycha. „Brylują posłowie LPR, którzy urządzają szopki w stylu wystawy o aborcji, gdzie znalazły się zdjęcia dzieci z obozu koncentracyjnego" ${ }^{21}$.

Inne zalety funkcjonowania Europarlamentu dostrzegła Dominika Cosić, korespondentka tygodnika „Wprost”. W artykule Po co nam Europarlament?, porównała go do starożytnej agory, gdzie ma miejsce żywa polemika i częste konfrontacje poglądów. Do najbardziej barwnych postaci europejskiej sceny politycznej, których wystąpienia w Strasburgu wywołały najwięcej kontrowersji, a nawet awantury zaliczyła Silvio Berlusconiego, Jean-Marie Le Pena, Alessandre Mussolini (wnuczkę faszystowskiego przywódcy Benito Mussoliniego). Zwróciła również uwagę na wkład Polski w parlamentarne skandale: m.in., wystapienia prof. Macieja Giertycha i jego wypowiedzi na temat teorii ewolucji oraz happeningi Witolda Tomczaka z LPR, który podczas debaty w Europarlamencie podarował deputowanym - ,najcenniejszy skarb narodu polskiego krzyż - Chrystusowy"22.

Publicystka „Newsweeka” za niski stan wiedzy społeczeństwa na temat Europarlamentu obwiniała media, którym umykały w wiadomościach rzeczywiste pozytywne strony działalności Parlamentu Europejskiego. „Rzekomy gwałt eurodeputowanego Bogdana Golika na prostytutce to najlepiej zapamiętane przez Polaków wydarzenia kojarzące się z rodzimymi eurodeputowanymi” ${ }^{23}$. Dodała również, że sesje Europarlamentu nie są porywające, a obywatele Unii nie mają wpływu np. na obsadę stanowiska szefa Komisji Europejskiej. W ten sposób starała się wytłumaczyć apatię społeczną spowodowaną brakiem wiary w siłę oddanego głosu.

Roman Holzer na łamach „Rzeczpospolitej” zakładał pesymistycznie, że wybory do PE zlekceważy większość społeczeństwa, ponieważ państwa nie znalazły sposobu, aby przekonać obywateli, że mają coś ważnego załatwić w Strasburgu. Podkreślił, że jeśli czarny scenariusz się sprawdzi Polska, wielki bojownik o wolność aczkolwiek niedojrzały do wspólnotowego myślenia, nie będzie poważnie traktowana na arenie międzynarodowej: „...nasi politycy krytykują politykę wschodnią Francji i Niemiec, postulują solidarność energetyczną, domagają się uznania dla narodowej martyrologii i niczym bohater opowiadania Sławomira Mrożka pokazują dawno stracony ząb, krzycząc, o tu za wolność wybili, ale robią to wszystko bez realnego wsparcia wyborców, których sprawy publiczne niezbyt obchodzą i którzy niewiele z nich rozumieją"24.

Publicysta „Rzeczpospolitej” postawił też tezę, że nasza obojętność może Polskę drogo kosztować: ,... to argument dla tych, którzy będą walczyć o zmniejszenie dotacji

20 J. Kowalska-Iszkowska, Odsiecz ze Strasburga, „Newsweek - Polska”, 7 czerwca 2009, s. $17-18$.

21 Ibidem.

22 D. Cosić, Po co nam Europarlement?, „Wprost”, 31 maja 2009, s. 32.

23 Ibidem.

24 R. Holzer, Chłód przed eurowyborami, „Rzeczpospolita”, 3 czerwca 2009, s. 18. 
dla naszego regionu w następnym unijnym budżecie na lata 2014-2020. Także dla tych, którzy chcą przekonać zachodnioeuropejską opinię publiczną, że relacje Bruksela-Moskwa rozwijałyby się znacznie lepiej, gdyby Warszawa się do nich nie wtrącała"25.

Na tydzień przed wyborami w prasie codziennej, m.in., „Gazeta Wyborcza” „Rzeczpospolita”, „Dziennik” pojawiły się szczegółowe informacje ze wszystkich okręgów wyborczych. Analizowano postępy przeprowadzonych kampanii oraz próbowano odgadnąć preferencje wyborcze społeczeństwa. Publicyści prasy zgodni byli w opinii, że zbliżająca się do końca kampania wyborcza do Parlamentu Europejskiego przeprowadzona została niskim nakładem sił i środków oraz bez pomysłu i w sposób mało interesujący.

1 czerwca „Gazeta Wyborcza” donosiła o dosłownym ,znudzeniu” społeczeństw europejskich kampanią wyborczą której po pierwsze do końca nie rozumieją, a po drugie nie bardzo wieżą w siłę oddanego przez siebie głosu. $\mathrm{Z}$ przeprowadzonego przez Parlament Europejski sondażu wynikało, że frekwencja zapowiada się rekordowo niska. Na pytanie czy na pewno zagłosujesz w wyborach do PE tylko $43 \%$ respondentów odpowiedziało twierdząco ${ }^{26}$.

Zdaniem publicystki „Gazety Wyborczej” - Dominiki Pszczółkowskiej mamy do czynienia z pewnego rodzaju paradoksem. Gdy Parlament nie miał żadnej władzy frekwencja była wysoka. Dziś, gdy współdecyduje prawie o wszystkim, obywatele prawie się nim nie interesują. Innym powodem niechęci elektoratu była zbyt skomplikowana struktura instytucji unijnych, trudna do odczytania dla przeciętnego człowieka. „W Europarlamencie nie ma wyraźnego podziału na koalicję i opozycję. Ludzie nie wiedzą, co zmieni ich głos. ${ }^{27}$ - komentował Jaques Rupnik, dyrektor badań w paryskim Instytucie Nauk Politycznych.

Tego samego dnia na łamach „Gazety” opublikowano sondaż, który zapowiadał niespodziankę. Okazało się, że województwie kujawsko-pomorskim, na Podlasiu, Warmii i Mazurach największy poziom poparcia osiagnęła Platforma Obywatelska zgarniając ponad połowę głosów ${ }^{28}$. Zdaniem publicysty Wojciecha Szackiego wyraźne prowadzenie PO w województwie kujawsko-pomorskim spowodowane było przede wszystkim chybionym osadzeniem na 1 miejscu listy PiS słabo rozpoznawanego w Toruniu i Bydgoszczy Ryszarda Czarneckiego. Sam zainteresowany nie chciał wdawać się w merytoryczną polemikę trwającej kampanii. Zasugerował tylko, że „walka o mandat trwa, a liczy się ten, kto na mecie jest pierwszy, a nie kto wygrywa lotne premie" $^{29}$. Szacki zwrócił też uwagę na sytuację w regionie Kujaw i Pomorza. Tam liderował Tadeusz Zwiefka, który mógł liczyć na 20\% głosów elektoratu.

W artykule omówiono również względnie wysokie notowania Janusza Zemke (SLD) 12,6\%, Eugeniusza Kłopotka (PSL) 4,3\% oraz silną pozycję Jacka Kurskiego na Warmii i Mazurach, który według sondażu mógł liczyć na 14,8\% głosów: ,....Jestem najsilniejszym kandydatem jako przybysz z Gdańska. Regionalizmy nie mają znaczenia. Ludzie postawili na wyrazistość. Mamy być przecież reprezentacją Polski

25 Ibidem

26 D. Pszczółkowska, Europa znudzona wyborami, „Gazeta Wyborcza”, 1 czerwca 2009, s. 10.

27 Ibidem.

28 W. Szacki, Mazowsze dla Prawa i Sprawiedliwości, „Gazeta Wyborcza”, 1 czerwca 2009, s. 4.

29 Ibidem. 
w Brukseli”30 , komentował Kurski. Z kolei w okręgu warmińsko-mazurskim oraz na Podlasiu respondenci największym zaufaniem obdarzyli połów PO, m.in.: Beatę Bublewicz 8,5\%, Tadeusza Arłukowicza 5,5\%, Krzysztofa Liska 4,0\%.

W „Dzienniku” komentowano konwencję wyborczą Prawa i Sprawiedliwości. Na specjalne zaproszenie Jarosława Kaczyńskiego 30 maja w Warszawie gościli: prezes czeskiej konserwatywnej partii Obywatelska Partia Demokratycznej, były premier - Mirek Topolanek oraz szef brytyjskich konserwatystów David Cameron. Podczas spotkania zawiązano frakcję, która po wyborach miała wspólnie zasiadać w Europarlamencie. Głównym celem działalności połączonych sił PiS-u, brytyjskich Torysów i czeskich konserwatystów miała być walka z europejską biurokracją, odblokowanie gospodarki, otwarcie rynków, postanowień przede wszystkim zmiana postanowień Traktatu lizbońskiego ${ }^{31}$.

Analizując geografię wyborów politycznych polskiego społeczeństwa na łamach „Rzeczpospolitej” zwrócono uwagę na utrzymującą się w większości okręgów wyborczych w Polsce przewagę PO nad innymi partiami w wyścigu do foteli w Strasburgu. Zauważono też, że w niektórych regionach Polski wzrosło poparcie dla Prawa i Sprawiedliwości. Tak było na przykład w województwie małopolskim (wzrost poparcia z $32 \%$ do $37 \%$ ), przy jednoczesnym spadku poparcia dla PO (z $42 \%$ do $38 \%$ ). Znanego socjologa Jarosława Flisa nie dziwiła taka sytuacja, gdyż od samego początku kampanii PiS postawił na swe mateczniki. W jego opinii sprawdzała się strategia nastawiona na mobilizację swojego elektoratu ${ }^{32}$. $\mathrm{Z}$ kolei PO prowadziła głównie w dużych miastach - Warszawa, Olsztyn.

Na tydzień przed wyborami, we Wrześni i Opocznie odbyły się już tradycyjnie prawybory. Według publicystów prasy polskiej ich wynik nie był miarodajnym wskaźnikiem poparcia dla któregokolwiek ugrupowania politycznego. Główną cechą prawyborów był deficyt frekwencji zauważalny nie tylko wśród elektoratu, ale również niektórych partii. „PiS zbojkotował wybory... SLD rozdawała watę cukrową... Działacze Samoobrony rozdawali biało-czerwone krawaty i ulotkę z napisem zabezpiecz się przed PiS ${ }^{\prime 33}$. W obu miastach zwyciężyła Platforma Obywatelska.

Kolejne dni kampanii sugerowały, że pomimo relatywnego spadku poparcia dla partii Donalda Tuska w okręgach wrocławskim, poznańskim, lubuskim, PO nadal utrzymuje przewagę nad innymi partiami. Zdaniem Bartłomieja Biskupa z Uniwersytetu Warszawskiego ,pierwsze miejsce jest niezagrożone, pytanie tylko czy będzie to poparcie sięgające 30,40 , czy $50 \%{ }^{\circ 34}$. Warszawski politolog zauważył również, że w niektórych okręgach względnie rosnące poparcie dla PiS spowodowane jest reakcją prezesa Jarosława Kaczyńskiego na odezwę niemieckich chadeków potępiającą wypę-

30 Ibidem.

31 Zob. szerzej: M. Duda, G. Osiecki, PiS tworzy frakcję razem z czeska ODS, i torysami, „Dziennik", 1 czerwca 2009, s. 4; Libertas też może wejść do frakcji jeśli chce reformy, rozmowa z Dawidem Cameronem, „Dziennik”, 1 czerwca 2009, s. 4; M. Karnowski, Z Cameronem pod rękę, „Dziennik”, 1 czerwca 2009, s. 1.

32 K. Manys, PiS odzyskuje mateczniki, „Rzeczpospolita”, 1 czerwca 2009, s. 3.

33 Ł. Zalesiński, M. Goss, Prawybory: wata i nikła frekwencja, „Rzeczpospolita”, 1 czerwca 2009, s. 4.

${ }^{34}$ K. Manys, J. Stróżyk, Antyniemiecki as w rękawie, „Rzeczpospolita”, 2 czerwca 2009, s. 3. 
dzenia. Hasła te miały wpłynąć na postawy społeczeństw w zachodnich regionach Polski, szczególnie wrażliwych na tę kwestię.

3 czerwca, na podstawie badań sondażowych przeprowadzonych w kilku regionach Polski prasa donosiła o możliwym powrocie na scenę polityczną Samoobrony. Choć partia Andrzeja Leppera ciągle znajdowała się wśród ugrupowań niemogących przekroczyć wymaganego progu wyborczego, to jednak w czterech okręgach: bydgoskim, gorzowskim, katowickim i lubelskim przekroczyła 5\%, a w dwóch innych: gdańskim i łódzkim zbliżyła się do tej liczby. Z sondaży wynikało, że wyborcy zapalili dla lidera ugrupowania zielone światło. Choć sam z żadnej listy nie kandydował, nie ukrywał wielkiego zadowolenia: „Naszym celem jest powrót do sejmu”35, zadeklarował Andrzej Lepper.

„Dziennik” zwrócił uwagę na nowy wizerunek przywódcy Samoobrony, którym chciał zachęcić elektorat do głosowania na jego partię. Tym razem w wyglądzie Leppera przyciagał uwage nie biało-czerwony krawat, ale szeroka i błyszcząca, jakby specjalnie wypolerowana obrączka. Publicystka działu ,polityka” „Dziennika”, Kamila Wronkowska podkreśliła, że to nie przypadek, ale przemyślana taktyka specjalistów od wizerunku politycznego. „To swoista próba oczyszczenia wizerunku przywódcy Samoobrony uwikłanego w seksaferę"36.

3 czerwca „Gazeta Wyborcza” opublikowała sondaż z kolejnych okręgów Polski: podkarpackiego, śląskiego, małopolskiego i świętokrzyskiego. Ku zaskoczeniu obserwatorów sceny politycznej, znany bastion PiS-u - Podkarpacie był bardziej przychylny dla partii Donalda Tuska aniżeli dla Jarosława Kaczyńskiego.

Według publicystów „Gazety” tak zaskakujący wynik był rezultatem oddania pierwszego miejsca na liście PO - Marianowi Krzaklewskiemu. Choć wielu działaczy Platformy (Elżbieta Łukacijewska, Tomasz Kulesza) nie ukrywało zdziwienia decyzją klubu parlamentarnego PO, a nawet ostro ją krytykowało, to silna pozycja Krzaklewskiego otwierała szansę na drugi mandat w tym regionie i pozyskanie głosów osób niezdecydowanych.

W Krakowie na liście PiS niepodważalną pozycję miał Zbigniew Ziobro, który mógł cieszyć się poparciem 20\% respondentów - ponad dwie trzecie tego co cała lista PiS w okręgu. Drugi na liście PiS, Paweł Kowal, zdaniem „Gazety” - w ogóle nie zaistniał $^{37}$. Najsilniejszym konkurentem dla Zbiory miała być Róża Thun z poparciem sięgającym $22 \%$. O trzecie miejsce w okręgu walczyło dwóch innych działaczy PO - Konstanty Miodowicz i Bogusław Sonik.

Na Śląsku liderem nie tylko okręgu, ale i całej Polski pozostawał Jerzy Buzek, który mógł cieszyć się poparciem 30\% wyborców. Drugie miejsce zajmował Marek Migalski z PiS (4,7\%). W batalii o Strasburg mieli się również liczyć Adam Gierek z SLD (2,9\%) oraz dwóch kandydatów z PO - Jan Olbrycht (3,9\%) oraz Małgorzata Handzlik (2,8\%). W tym regionie najsłabiej wypadało Polskie Stronnictwo Ludowe (poparcie siegało tylko 2\%). Tego samego dnia publicyści „Dziennika” zwrócili uwagę na zaniepokoje-

35 K. Manys, Lepper odżywa w eurokampanii, „Rzeczpospolita”, 3 czerwca 2009, s. 4.

36 Zob. szerzej, K. Wronkowska, Lepper towi wyborców na obrqczkę, „Dziennik”, 2 czerwca 2009, s. 7.

37 W. Szacki, Jerzy Buzek znów pobije rekord?, „Gazeta Wyborcza”, 3 czerwca 2009, s. 4. 
nie sztabowców Platformy niepewną sytuacją w regionach Mazowsza, Podkarpacia i Małopolski oraz zmianą preferencji wyborczych społeczeństwa. W związku z powyższym, twarzą ostatnich dni kampanii miał być Donald Tusk, a nową taktyką obraną przez liberałów miało być dyskutowanie podczas spotkań problemów krajowych, a nie międzynarodowych, europejskich: „....na ostatniej konwencji w Łodzi może jedna trzecia wystapienia Tuska dotyczyła Europy. Reszta to sprawy wewnętrzne, bo tylko takie ludzi naprawdę interesują"38.

4 czerwca „Gazeta” opublikowała kolejne wyniki sondażu tym razem z Warszawy, Pomorza, woj. lubuskiego i Dolnego Śląska. Z badań wynikało, że w stolicy zarysowała się wyraźna przewaga PO nad PiS. Według sondażu na Danutę Hübner głos miało oddać 27,3\% wyborców, a na Michała Kamińskiego 6,4\%. Badania wskazywały również, że spośród innych ugrupowań pewnym mandatu mógł być Wojciech Olejniczak z SLD-UP (5,8\%) oraz Paweł Zalewski z PO (5,4\%).

Z kolei, na Dolnym Śląsku, znanym bastionie PO, sondaż na pierwsze miejsce wysuwał kandydaturę Jacka Protasiewicza (PO). Zdaniem publicystów „GW” w tym regionie w walce o głosy wyborców liczyli się również inni działacze Platformy Piotr Borys $(4,0 \%)$ oraz Danuta Jazłowiecka $(3,4 \%)$. Wśród kandydatów lewicy przewodziła Lidia Geringer Oedenberg (5,2\%), a w PiS-ie Ryszard Legutko (4,8\%).

W innym regionie kraju, na Pomorzu prowadził Sławomir Nitras z PO $(15,4 \%)$, który ostro krytykował formę kampanii prowadzonej przez PiS. Jego zdaniem oparta była na zastraszaniu społeczeństwa rzekomymi roszczeniami Niemców. „Jak można było w tym okręgu straszyć Niemcem? W Szczecinie nie znam nikogo, kto by się tym przejął. Może na Mazowszu PiS dopomogło, ale na tu pewno stracił”39 ${ }^{39}$ - skomentował Nitras.

Zdaniem „Gazety”, w Zielonej Górze godnym odnotowania był wynik osiagnięty przez Krzysztofa Machalicę - trenera Zastalu Zielona Góra, syna nieżyjącego aktora Henryka Machalicy. Mógł on liczyć na poparcie 3,4\% głosów.

Tego samego dnia w „Dzienniku”, przedstawiono wstępny raport Fundacji Batorego o finansowaniu kampanii wyborczej do Europarlamentu. Wynikało z niego, że politycy zarówno z prawej, jak i lewej części polskiej sceny politycznej naginają ordynację wyborczą do własnych celów wyborczych. „Danuta Hübner (PO) w swojej kampanii wykorzystywała służbowy samochód Komisji Europejskiej, Tomasz Arłukowicz (PO), na specjalnych, ale nieoznakowanych logo partii plakatach życzył maturzystom powodzenia, Ryszard Czarnecki (PiS), promował się na plakatach finansowanych przez jedną z frakcji Parlamentu Europejskiego, Sylwia Pusz (SLD), prowadziła w jednej z lokalnych telewizji program, który promowała na plakatach ze swoim wizerunkiem" ${ }^{40}$.

Zdaniem Kamili Wronkowskiej publicystki „Dziennika”, nadużycia zauważamy też na stronach internetowych kandydatów, często zakładanych tylko na potrzeby eurokampanii. Wszystkie te koszty powinny się znaleźć w sprawozdaniach wyborczych. Tuż przed wyborami prasa polska przewidywała zwycięstwo Platformy Obywatelskiej, dla której poparcie sięgnąć miało około $47 \%$ głosów. Z przeprowadzonych sondaży

38 A. Gielewska, G. Osiecki, Donald Tusk musiał przejąc kampanię, „Dziennik”, 3 czerwca 2009,

39 W. Szacki, Stolica Platformy, „Gazeta Wyborcza”, 4 czerwca 2009, s. 4.

40 K. Wronkowska, Jak eurokandydaci omijaja prawo, „Dziennik”, 4 czerwca 2009, s. 7. 
wynikało również, że pewni obsadzenia foteli w Strasburgu mogą być przedstawiciele partii Prawo i Sprawiedliwość (około 26\% głosów), SLD-UP (około 10\% głosów), PSL (7\% głosów). Poza progiem wyborczym ciągle pozostawały: Samoobrona, Libertas Polska, Centrolewica, Prawica RP, UPR, PPP ${ }^{41}$.

4 czerwca, na finiszu kampanii, o udział w wyborach do Parlamentu Europejskiego zaapelowała wspólnie lewa strona polskiej sceny politycznej: SLD, UP, Krajowa Partia Emerytów i Rencistów, Polska Lewica, Ruch Odrodzenia Gospodarczego, Stowarzyszenie Ordynacka, Stowarzyszenie Smolna oraz Weterani Lewicy. Apel bazował na kilku nośnych propagandowo hasłach: „,nie bójmy się powrotu PiS do władzy”, „Pokażmy czerwoną kartkę całej kłócącej się prawicy”, , wyborcy, którzy oddali głos w wyborach z 2007 roku na PO - Wracajcie do nas!"42.

Dzień przed ciszą wyborczą w prasie polskiej pojawiły się pierwsze komentarze oceniające merytoryczny poziom kampanii, nastroje społeczne oraz zaangażowanie polityków w Eurowybory. „Gazeta Wyborcza” przedstawiła nazwiska pewnych zwycięzców. Na liście znaleźli się: Jerzy Buzek (Śląsk), Danuta Hübner (Warszawa), Sławomir Nitras (Pomorze Zachodnie), Janusz Lewandowski (Pomorze), Jacek Saryusz Wolski (woj. łódzkie) oraz kandydatów balansujących na granicy zwycięstwa i porażki, walczących do ostatniej chwili o mandat. Tak było w przypadku wewnętrznej rywalizacji pomiędzy członkami PO - Elżbietą Łukaciejewską oraz Marianem Krzaklewskim. Okazało się, że taktyka obrana przed wyborami przez PO na Podkarpaciu sprawdzała się. $Z$ badań sondażowych wynikało, że były lider AWS zabierze głosy PiS, ale nie było pewne, że sam otrzyma mandat ${ }^{43}$.

Z kolei „Dziennik” zapowiadał gorącą walkę o pierwsze miejsce w Bydgoszczy pomiędzy Januszem Zemke (SLD) i Tadeuszem Zwiefką (PO), a także ,jedynkami” innych partii w tym regionie Eugeniuszem Kłopotkiem (PSL) i Ryszardem Czarneckim (PiS) - obaj mieli po $11 \%$ głosów poparcia ${ }^{44}$.

Na łamach „Rzeczpospolitej” sugerowano, że kampania wyborcza do Europarlamentu jest nie tylko walką o mandaty, ale również grą polityczną na rodzimym podwórku, w której każda z partii ma mniej lub bardziej ukryty interes: „Wojciech Olejniczak (SLD) przeniósł się do Warszawy, aby budować swoją pozycję przed przyszłorocznymi wyborami samorządowymi... Elżbieta Jakubiak (PO) i Paweł Poncyliusz (PiS) traktowali kampanię jako rozgrzewkę przed wyborami na prezydenta Warszawy... Jolanta Szczypińska chciała otrzymać na Pomorzu schedę po Jacku Kurskim... Ludowcy nie kryli, że wybory chcą wykorzystać do wzmocnienia swojej pozycji w koalicji”45.

5 czerwca podczas konwencji w Radomiu Jarosław Kaczyński zakończył kampanię wyborczą do Europarlementu. Zachęcał zebranych do głosowania na przedstawicieli PiS, bo tylko oni byli w stanie wyciagnąc z UE - zgodnie z hasłem wyborczym PiS - więcej dla Polski. Prezes PiS-u postulował zmianę wizerunku Unii. „...Unia musi być

\footnotetext{
41 Zob. szerzej dane przedwyborczego sondażu przygotowanego przez Homo Domini na zlecenie „Dziennika” oraz Polsatu, w: „Dziennik”, 5 czerwca 2009, s. 1.

${ }^{42}$ Apel o udziat w wyborach do Parlamentu Europejskiego, „Trybuna”, 4 czerwca 2009, s. 3.

43 W. Pelowski, Pelowski, M. Bujara, W. Szacki, Pewniacy $i$ zagadki, „Gazeta Wyborcza”, 5 czerwca 2009 , s. 8.

44 K. Wronkowska, Warszawa dla PO, PS bierze Kraków, „Dziennik”, 5 czerwca 2009, s. 8.

45 K. Manys, Walka o euromandaty, nie tylko, „Rzeczpospolita”, 5 czerwca 2009, s. 6.
} 
inaczej skonstruowana. Unia uwzględniająca realia, Unia w której nie ma jednego, szczególnie dzisiaj groźnego zjawiska, w której nie ma hegemonii. Unia ma być sprawnym mechanizmem europejskiej współpracy między państwami. Musi być oparta o zasady solidarności, a z tych zasad solidarności wynika to, co jest naszą szansą: więcej dla Polski’”“

Tuż przed wyborami wspomniany już socjolog Jarosław Flis na łamach „Tygodnika Powszechnego" sugerował, że o sprawach publicznych decydują bardzo często niuanse - i to jest dużą zaletą zbliżających się wyborów. „Dlatego kandydaci powinni nie tylko być: doświadczeni, sprawni, uczciwi, atrakcyjni, błyskotliwie dyskutować czy sprawnie „menedżerować”, mieć określoną przeszłość - powinni wszystkie te elementy połączyć w jedną całość i unikać błędów na każdym z tych pól. Niuanse te tworzą pewną całość, a obowiązkiem każdego polityka jest uszanować preferencje wyborów, nawet jeśli wydają mu się drugorzędne"47.

Dzień przed ciszą czołowy polityk PSL Stanisław Żelichowski zaapelował do rolników i mieszkańców wsi o aktywne uczestnictwo w wyborach. Podziękował kandydatom swojego ugrupowania za odbycie wielu spotkań z elektoratem, których celem była m.in., walka o dopłaty dla rolników. Wiceprezes PSL Jarosław Kalinowski zauważył, że sprawy rolnictwa były niezwykle ważną częścią debaty wyborczej. Nawet nasi partnerzy koalicyjni pokazali, że rolnictwo jest im bliskie, wszystkie komitety kochały wieś i rolnictwo" ${ }^{\circ 8}$.

\section{Po wyborach}

W poniedziałek 8 czerwca, w prasie polskiej pojawiły się pierwsze, niepotwierdzone jeszcze rezultaty wyborów do Parlamentu Europejskiego w Polsce. Wynikało z nich, że choć w porównaniu do ostatnich wyborów do PE frekwencja była o kilka procent wyższa i sięgnęła $24,5 \%$, to i tak był to jeden z najgorszych wyników w historii wyborów do Europarlementu.

„Dziennik” opublikował wyniki, które potwierdziły zapowiadany przed wyborami prymat Platformy Obywatelskiej nad innymi ugrupowaniami politycznymi. Partia Donalda Tuska zdobyła 25 mandatów, a głosowało na nią 44,4\% wyborców. Tuż po wyborach szef Sejmowej Komisji Spraw Zagranicznych Krzysztof Lisek zasugerował, że zwycięstwo PO przynosi wiele korzyści, a już na pewno zdecydowanie zwiększa szansę Jerzego Buzka w walce o fotel przewodniczącego Parlamentu Europejskiego: „kandydatura Buzka ma duże szanse na absolutne poparcie wszystkich nowych krajów członkowskich. Na pewno to Jerzy Buzek, a nie Mario Mauro jest niekwestionowanym liderem w naszym regionie. Pozytywne sygnały na temat kandydatury Buzka płyną też z Hiszpanii i Szwecji” ${ }^{49}$.

46 Zob. szerzej, Finat kampanii wyborczej PiS, „Polska Scena Polityczna”, 1-15 czerwca 2009, s. 15.

47 J. Flis, Eurodecyzje, „Tygodnik Powszechny”, 7 czerwca 2009, s. 10.

48 Zob. szerzej, Finat kampanii wyborczej PSL, „Polska Scena Polityczna”, 1-15 czerwca 2009, s. 10.

49 Zob. szerzej wypowiedź szefa sejmowej komisji ds. zagranicznych Krzysztofa Liska na temat szansy objęcia fotela przewodniczącego Parlamentu Europejskiego przez Jerzego Buzka, „Polska Scena Polityczna", 1-15 czerwca 2009, s. 7-8. 
Na drugim miejscu z poparciem sięgającym prawie $27,4 \%$ uplasował się PiS. Partii Jarosława Kaczyńskiego wynik ten pozwalał obsadzić 15 miejsc w Europarlemencie. Trzecie miejsce zajęła koalicja SLD-UP uzyskując 7 mandatów (12,3\% głosów).

Choć politycy lewicy liczyli na lepszy wynik wyborów, to ogólnie byli względnie zadowoleni, że wyślą swoją reprezentację do Europarlementu. Dla byłego premiera Leszka Millera wynik potwierdził słuszność koncepcji obranej przez Grzegorza Napieralskiego, budowania wokół SLD struktury z zachowaniem tożsamości sojuszu. „Teraz SLD powinien przystapić do planu kooperacji i łączenia lewicy. Myślę, że wynik ten umacnia przekonanie, że SLD dalej pozostaje najważniejszą siłą po lewej stronie, koncepcja Marka Borowskiego poniosła fiasko" ${ }^{\$ 0}$.

9 czerwca sympatyzująca z ugrupowaniami lewicowymi „Trybuna”, na podstawie analizy Eurowyborów przestrzegła, że Europa skręca w prawo. Publicyści twierdzili, że w większości krajów europejskich (Hiszpania, Wielka Brytania, Niemcy, Litwa, Francja,) partie lewackie otrzymały od elektoratu żółtą kartkę. Ocenili, że na tym tle osiagnnięty przez komitet SLD-UP wynik jest przyzwoity. Częściową winą za niekorzystny dla całej lewicy europejskiej rezultat obarczyli utożsamienie ich z wyborami narodowymi. „kryzys poparcia dla socjalistów i socjaldemokratów odbierany jest jako efekt problemów wewnętrznych, niepowodzeń i krajowych skandali" ${ }^{51}$.

Zwrócono też uwagę, że czwarte miejsce zajęło PSL uzyskując 3 mandaty i 7,0\% głosów poparcia elektoratu. Progu wyborczego nie przekroczyły ugrupowania: Centrolewica, Samoobrona, UPR i Libertas.

Na łamach „Myśli Polskiej” oceniono zakończoną kampanię do Europarlamentu. Publicysta prawicowego tygodnika Maciej Eckardt postawił tezę, że preferencje społeczeństwa polskiego cechował racjonalizm. Polacy nie byli skłonni eksperymentować, ale stawiali na sprawdzone już marki. W powyborczym resume podkreślił hegemonię Platformy Obywatelskiej, twardość PiS-u oraz zawiedzione nadzieje SLD-UP. Wyniki ugrupowań prawicowych ocenił następująco: „UPR $(1,10 \%)$ - niewzruszony standard, Libertas $(1,14 \%)$ - wydmuszka, która okazała się zbukiem, Prawica Rzeczpospolitej (1,96\%) sympatyczni ludzie z niesympatycznym wynikiem"52.

W tym samym numerze dr Artur Górski z PiS-u na podstawie wyników wyborów diagnozował, że do nadejścia lepszych czasów, dla prawicy konserwatywnej Prawo i Sprawiedliwość będzie swoistą arką. „PiS musi być całkowitym dominantem po prawej stronie sceny politycznej... To da gwarancję, że pewna grupa polityków prawicowej ekstremy, czyli tradycyjnych konserwatystów przetrwa pod skrzydłami PiS, wybierana do parlamentu przez ideowy elektorat" ${ }^{\text {53 }}$. Przyłączenie się polityków LPR-u do Libertasu polityk PiS-u nazwał taktycznym błędem, przez który uciekła partii Romana Giertycha prawdziwa szansa na powrót na scenę polityczną. Górski uznał, że LPR jest mocniej zakorzeniony w świadomości prawicowego elektoratu aniżeli eksperymentalny Libertas.

50 Zob. szerzej, Politycy SLD liczyli najlepszy wynik wyborów, „Polska Scena Polityczna”, 1-15 czerwca 2009, s. 30.

51 A. Rosolak, E. Latosek, Prawa marsz, „Trybuna”, 9 czerwca 2009, s. 1.

52 M. Eckardt, No i po wyborach, „Myśl Polska”, 21-28 czerwca 2009, s. 4.

53 A. Górski, Krajobraz po bitwie, „Myśl Polska”, 21-28 czerwca 2009, s. 5. 
Inny publicysta tygodnika Maciej Motas poszukiwał również przyczyn klęski Libertasu w Eurowyborach. Wśród najważniejszych powodów wymienit: brak wyraźnej różnicy pomiędzy Libertas - Polska, a innymi prawicowymi ugrupowaniami, a szczególnie PiS, sięganie podczas kampanii do haseł sprzed akcesji Polski do Unii Europejskiej oraz brak merytorycznej kampanii, która sprowadzała się właściwe do programu negacji ${ }^{54}$.

14 czerwca do dyskusji na temat wyników Eurowyborów przyłączył się również „Zielony Sztandar”. Dziennikarze sympatyzującego z PSL-em tygodnika zgodni byli w opinii, że dobry wynik, jaki osiagnęło ugrupowanie Waldemara Pawlaka jest rezultatem rzetelnej, prowadzonej na wysokim poziomie merytorycznej kampanii wyborczej. Ponadto zadecydowały o tym również dwie istotne przesłanki: prowadzenie kampanii pozytywnej oraz rozpoznawalność kandydatów. „Nasi kandydaci startowali z miejscowości, w których mieszkają. Znani w swoich okręgach wyborczych z nazwiska i dobrej pracy" ${ }^{, 55}$.

Oceniając wybory do PE na starym kontynencie publicyści prasy polskiej zgodni byli w opinii, że nastroje europejskie zaczynają sprzyjać postawom nacjonalistycznym, ksenofobicznym i nietolerancyjnym skłaniającym raczej do przyhamowania tempa integracji aniżeli jego pogłębiania. „Wprawdzie polska reprezentacja konserwatystów z PiS-em nie domaga się „Polski dla Polaków”, to dawniej gloryfikowana i hołubiona przez Europejczyków otwartość zaczyna przeszkadzać: Belgom, Holendrom, Duńczykom, Austriakom, Brytyjczykom”. Dlatego, zdaniem publicysty „Gazety” ważne miejsce w nadchodzącej kadencji Europarlamentu miały zająć połączone siły brytyjskich konserwatystów z polskim PiS oraz czeskim ugrupowaniem prawicowym ODS, które zdecydowanie zwyciężyło w kraju naszych południowych sąsiadów.

Polscy komentatorzy sugerowali również, że Europarlament w nowej odsłonie, z większą ilością eurosceptyków, co najwyżej eurorealistów będzie bardziej antyeuropejski ${ }^{57}$. Przyczyn takiej sytuacji upatrywali m.in. w kryzysie finansowym, czego odzwierciedleniem była niechęć elektoratu do głosowania na przywódców partii politycznych rządzących w kraju, szczególnie charakterystyczna dla małych krajów UE.

Zauważyli również, że w całych wyborach europejskich - pomimo odejścia z frakcji brytyjskich konserwatystów - zwyciężyli chadecy przed socjalistami i liberałami. Przestrzegano jednak przed lekceważeniem i niedocenianiem roli mniejszych partii w ogólnym wpływie na decyzje PE. Sugerowano, że pomimo różnych poglądów mogą nie utworzyć wspólnej frakcji, ale na pewno mogą „żądać wysokiej ceny od grup, którym do ukonstytuowania się będzie brakowało pojedynczych osób z pojedynczych krajów Unii”, ${ }^{\prime 5}$.

Wszystkie czasopisma i gazety zgodnie krytykowały polityków i uczyniły ich winnymi niskiej frekwencji wyborczej w Polsce. Marek Cichocki - ekspert ds. europej-

${ }^{54}$ Zob. szerzej, M. Motas, Libertas - klęska totalna, „Myśl Polska”, 21-28 czerwca 2009, s. 6.

55 Pozytywna i merytoryczna kampania, „Zielony Sztandar”, 14 czerwca 2009, s. 2.

56 Zob. szerzej, J. Pawlicki, Eurostrachy na lachy, „Gazeta Wyborcza”, 8 czerwca 2009, s. 1.

57 Zob. szerzej, D. Przszczółkowska, Euroscepcja, „Gazeta Wyborcza”, 8 czerwca 2009, s. 2.

58 A. Słojewska, Chadecy, socjaliści, liberałowie, „Rzeczpospolita”, 8 czerwca 2009, s. 4. 
skich zasugerował, że elity polityczne chciały walczyć z deficytem demokracji w Unii, przybliżyć ją obywatelom, ale nie przyniosło to rezultatów"

Piotr Skwieciński na łamach „Rzeczpospolitej” wyliczył najważniejsze kompetencje PE i podkreślił jego rosnące znaczenie już od Traktatu z Maastricht. Ubolewał tym samym nad niskim stanem świadomości społeczeństwa polskiego odrzucającego udział w wyborach. W swoim artykule replikował innemu znanemu publicyście Bronisławowi Wildsteinowi, który opublikował artykuł sugerujący niskie znaczenie PE w strukturze instytucjonalnej UE ${ }^{60}$. Publicysta popularnej „Rzepy”, do najważniejszych kompetencji PE zaliczył: zależność polskiego prawa od prawa UE - prawie w trzech czwartych. Ponadto zauważył, że PE coraz częściej ma decydujący wpływ na unijne prawodawstwo w szczególnie ważnych dla Polaków obszarach jak: ,przepływ pracowników, badanie i rozwój technologiczny, ochrona środowiska, ochrona konsumentów, edukacji, kultury, zdrowia, całokształtu regulacji rynku wewnętrznego od Atlantyku po Bug"61.

Były prezes Polskiej Agencji Prasowej brak świadomości i wiedzy na temat zakresu i działania PE tłumaczył m.in., niepewnością samego Europarlamentu, co do egzekwowania swoich kompetencji. Ponadto sugerował, że niedocenianie czy wręcz niezrozumienie statusu instytucji PE jest bolączką pokutującą w całym kraju: „Ta świadomość jest ciagle w Polsce bardzo wyspowa. W efekcie wszyscy - od kluczowych sektorów polskiego przemysłu, przez kolejne zainteresowane różnorodną problematyką organizacje non-profit - zbyt często przegrywamy różne szanse. Nie korzystamy z możliwości wpływania na europejskie regulacje w momencie, w którym jest to najłatwiejsze - czyli wtedy kiedy one przechodzą przez komisje PE"62.

10 czerwca „Gazeta Polska” oceniła zakończoną kampanię do Europarlementu. Publicyści tygodnika sugerowali, że względna porażka ugrupowań prawicowych jest powodem deficytu jedności i wspólnego przedstawicielstwa: „Prawica RP zdołała zaistnieć dzięki Wojciechowi Cejrowskiemu, a Libertas za pomocą TVP. Jednak w obu przypadkach było to za mało, by coś ugrać. Dla polskiego Libertasu gwoździem do trumny była krytyka ze strony ojca Rydzyka. Ugrupowania te musiały też dodatkowo rywalizować z UPR" ${ }^{\prime 63}$.

13 czerwca publicysta „Polityki” Mariusz Janicki postawił tezę, że wyniki Eurowyborów nikogo w Polsce nie zaskoczyły. Platforma wyraźnie wygrała, natomiast PiS przegrał, ale sromotnej klęski nie zanotował. Jego zdaniem nikogo nie dziwił też stały, żelazny elektorat SLD, a PSL jak zawsze mógł liczyć spokojnie na przekroczenie progu wyborczego. „Liczyły się tylko największe partie, pod małe szyldy nikt specjalnie nie zaglądał, dlatego przepadli tak wartościowi kandydaci jak Dariusz Rosati czy Janusz Onyszkiewicz z Centrolewicy" ${ }^{64}$.

${ }_{59}$ M. Sułdrzyński, A. Słojewska, Prawica pokieruje Unia, „Rzeczpospolita”, 9 czerwca 2009, s. 1; Niska frekwencja to wina polityków, rozmowa z biskupem Tadeuszem Pieronkiem, „Dziennik”, 8 czerwca 2009 , s. 6.

${ }_{60}$ Por. Wildstein, Europejski spektakl pozorów, op. cit., s. 2.

61 P. Skwieciński, Europarlament, cicha rosnaca potęga, „Rzeczpospolita”, 8 czerwca 2009, s. 15 .

${ }^{62}$ Ibidem.

63 P. Lisiewicz, Walka twardzieli bez nokautu, „Gazeta Polska”, 10 czerwca 2009, s. 4.

${ }^{64}$ M. Janicki, Każdy wziat swoje, „Polityka”, 13 czerwca 2009, s. 12. 
Mały udział społeczeństwa w Eurowyborach tłumaczył m.in., potwierdzoną reguła, że Eurowybory nie tylko w Polsce, ale również w Europie cieszą się dużo mniejszym zainteresowaniem w porównaniu do wyborów krajowych. Wśród innych przyczyn małego zaangażowania społeczeństwa wymienił brak rzetelnej, merytorycznej kampanii wyborczej: ,...kampania była marna, oparta na odgrzewanych chwytach, a sztaby wyborcze nie kryły, że skoro ordynacja wyborcza nie przewiduje w przypadku tych wyborów refundacji wydatków kampanii, to będzie ona oszczędnościowa, bo prawdziwe pieniądze są potrzebne, ale na batalię prezydencką w przyszłym roku i parlamentarną w 2011"65. Zdaniem Janickiego ta oszczędność, widoczna na bilbordach i plakatach nie mogła przykuć uwagi społeczeństwa i dlatego na spotkania z kandydatami przychodziło czasem nawet po kilka osób.

Prymat narodowych interesów państw członkowskich nad dobrem wspólnotowym podkreślił na łamach „Newsweeka” Paweł Świeboda. Dyrektor Centrum Strategii Europejskiej Demos Europa: „Partie startują pod narodowymi szyldami, a dopiero w PE łączą się we frakcje. Chadecy, ludowcy i umiarkowani konserwatyści tworzą tam na przykład Europejską Partię Ludową. Socjaldemokraci zrzeszeni są w partii Europejskich Socjalistów. Podczas debat nie ma jednak mowy o dyscyplinie partyjnej. Liczy się przede wszystkim narodowe interesy" ${ }^{16}$. Według Świebody nawet kryzys finansowy nie skonsolidował Europejczyków, gdyż każdy kraj ma na problemy gospodarcze indywidualny, narodowy program i receptę. Jego zdaniem Eurowybory stały się doskonałą okazją, by ponarzekać na Europę i obwinić Unię za narodowe problemy.

Podobne odczucia zdradzał dr Florian Trauner z Instytutu Badań nad Integracja Europejską w Wiedniu. Oceniając przebieg Eurowyborów zasugerował, że problemy wewnętrzne krajów członkowskich bardziej interesują społeczeństwo aniżeli skomplikowana problematyka unijna: „Polaków bardziej interesują problemy Stoczni Gdańskiej niż perspektywy członkostwa Turcji w UE. Brytyjczycy żyją skandalem z udziałem parlamentarzystów, którzy finansowali z publicznej kasy najbardziej absurdalne wydatki. W Hiszpanii emocje rozpalają rządowe propozycje liberalizacji prawa do aborcji" ${ }^{67}$.

20 czerwca na łamach „Polityki”, Janina Paradowska przedstawiła trzy symbole kampanii do Europarlementu 2009: Jerzego Buzka, Zbigniewa Zbiorę oraz Danutę Hübner, osoby, które otrzymały największą liczbę głosów poparcia podczas wyborów europejskich. Zauważyła, że powyborcze „rozdanie kart” jak na razie daje Donaldowi Tuskowi niezłą pozycję wyjściowa, ale to nie znaczy że wygrał. Eurowybory polskiemu premierowi przyniosły nie tylko sukcesy, ale co najmniej personalne dylematy, jeśli nie kłopoty. Jednym z nich był rezerwowany fotel europarlamentarzysty dla Danuty Hübner albo walka o kolejną kadencję dla byłej już komisarz UE. Możliwe byłoby również oddanie Hübner stanowiska związanego z gospodarką w rządzie, co zdaniem Paradowskiej najlepiej by do jej kompetencji pasowało. Znana publicystka tygodnika oceniła również, że ewentualna przegrana Jerzego Buzka w walce o fotel szefa PE przez opozycję będzie postrzegana jako osobista klęska premiera. $Z$ drugiej strony, wy-

65 Ibidem.

66 F. Gańczak, Europejska zadyszka, „Newsweek - Polska”, 14 czerwca 2009, s. 46.

67 Ibidem. 
nik najlepszy ze wszystkich kandydatów sugeruje, że prof. Buzek w przyszłości może wrócić na stanowisko premiera, a nawet prezydenta.

Według Paradowskiej wynik uzyskany przez PiS jest klęską i potwierdzeniem, że partia Jarosława Kaczyńskiego szybko nie wróci do władzy i musi zadowolić się miejscem opozycji. „PiS nie znajduje sposobu na powiększenie elektoratu, nie znajduje nowego języka w porozumiewaniu się z opinią publiczną i nie ma na horyzoncie potencjalnych koalicjantów" ${ }^{\text {"68 }}$. Sam Zbigniew Ziobro - jedyny prawdziwy zwycięzca opozycji - jest zdaniem Paradowskiej jedyną szansą dla partii Jarosława Kaczyńskiego na ewentualną reelekcję prezydenta Lecha Kaczyńskiego oraz na dobry wynik w wyborach parlamentarnych w 2011 roku. Publicystka przeanalizowała też geografię poparcia dla poszczególnych ugrupowań politycznych i postawiła tezę, że od dłuższego czasu w tym względzie wiele się nie zmieniło: ,są tereny gdzie bezapelacyjnie zwycięża, a nawet nieco poprawia swój wynik PO (polska północna i zachodnia), i takie, które pozostają królestwem PiS (Lubelszczyzna, Mazowsze, Podkarpacie)... duże miasta były za PO, w mniejszych lub zupełnie małych nie bez szans jest PiS... im ludzie młodsi i wykształcenie wyższe, tym częściej oddają głosy na PO, starsi i gorzej wykształceni na $\mathrm{PiS}^{69}$.

Silną pozycję Polski po Eurowyborach zaakcentowała publicystka „Newsweeka” Jolanta Kowalska-Iszkowska w artykule Więcej dla Polski, więcej dla Tuska. Podkreśliła, że mamy w Polsce rząd, który cieszy się niespotykanym w UE poparciem społeczeństwa, a wsparcie elektoratu dla PO w Eurowyborach wyeksponowało jeszcze mocniej jego proeuropejskie oblicze. Na tle ogólnoeuropejskiej ignorancji dla udziału w Eurowyborach Polska wypadła świetnie i to wynosi Polskę do roli aktywnego europejskiego gracza, który na salonach Brukseli będzie się liczył coraz bardziej. Podkreśliła również, że polscy politycy z Donaldem Tuskiem na czele w Europie mają szanse odgrywać coraz większą rolę m.in., dzięki swojej koncyliacyjnej postawie. Na gorąco po wyborach zauważyła też, że w przypadku zwycięstwa Jerzego Buzka w batalii o fotel szefa PE, szanse Janusza Lewandowskiego do objęcia fotela w Komisji Europejskiej będą oraz mniejsze ${ }^{70}$.

Na łamach dwutygodnika „Polska Scena Polityczna” przeanalizowano największe rozczarowanie wyborów i zapytano o przyszłość partii Libertas - paneuropejskiego stowarzyszenia, które w Eurowyborach poniosło druzgocącą klęskę. W ocenie Artura Zawiszy - wiceprezesa polskiego skrzydła Libertas: „,szyld Libertasu okazał się w tych wyborach niewystarczający i nie zachęcił zbytnio wyborców. Główną wartością polskiego Libertas nie była nazwa, lecz szerokie porozumienie środowisk prawicowych, m.in., PiS, LPR, „Naprzód Polsko”, „Stronnictwo Piast” ${ }^{\text {”11 }}$

Inny wiceprezes Libertas Polska Daniel Pawłowiec sugerował, że jej członkowie powinni zastanowić się nad dalszym funkcjonowaniem partii: „,musimy dokonać pew-

68 J. Paradowska, Trzy sukcesy, trzy kłopoty, „Polityka”, 20 czerwca 2009, s. 12.

${ }^{69}$ Ibidem.

70 Zob. szerzej, J. Kowalska-Iszkowska, Więcej dla Polski, więcej dla Tuska, „Newsweek - Polska”, 21 czerwca 2009, s. 27.

71 Zob. szerzej, Libertas Polska, „Polska Scena Polityczna”, Warszawa 1-15 czerwca 2009, s. 1. 
nej analizy, czy ten projekt ma szanse w Polsce się rozwinąć, bo w naszej ocenie wbrew wynikowi wyborczemu widać wyraźnie sens naszej działalności»’72.

Oceniając wybory do Parlamentu Europejskiego, publicyści prasy polskiej zgodni byli w opinii, że kampania wyborcza ukazała słabość polskich elit politycznych. W działalności ugrupowań zarówno z prawej, jak i lewej strony polskiej sceny politycznej zauważalny był brak pełnego zaangażowania w Eurowybory i brak odpowiednich środków do prowadzenia skutecznej kampanii. Nie przeprowadzono rzeczowej, merytorycznej kampanii, która przekonałaby sceptyczny elektorat do uczestnictwa. Ponadto sugerowano, że partie polityczne potraktowały Eurowybory jako „rozgrzewkę" przed zbliżającymi się wyborami prezydenckimi, a następnie parlamentarnymi. Prasa polska podkreślała również, że wyniki były do przewidzenia i tak naprawdę nikogo nie zaskoczyły. Partie polityczne kierowały się w nich sprawdzonymi metodami, chwytami, hasłami (odgrzebywanymi jeszcze sprzed akcesji Polski do UE), a także taktykami.

W prasie polskiej zwrócono uwagę, że lewica, już tradycyjnie starała się uświadomić elektoratowi, że jej program wyborczy jest alternatywą dla kłócących się w Parlamencie dwóch największych i najsilniejszych partii: PO i PiS ${ }^{73}$. A względnie przyzwoity wynik w wyborach zawdzięcza słabości centrolewicy i zaangażowaniu Aleksandra Kwaśniewskiego. Strategia PO z kolei oparta była na wzmocnieniu polskiej reprezentacji w PE czego dowodem było postawienie na Jerzego Buzka w batalii o fotel przewodniczącego PE. W tym miejscu warto zaznaczyć, że taktyka PO się opłaciła. 14 lipca Jerzy Buzek został wybrany szefem Parlamentu Europejskiego. Na 713 głosów otrzymał $555^{74}$.

Podkreślano, iż wynik osiągnięty przez Libertas Polska sugeruje jak ważne dla partii prawicowych - podzielonych i niejednolitych ideologicznie - jest zaangażowanie i wsparcie ojca Rydzyka oraz społeczności skupionej wokół Radia Maryja.

72 Ibidem.

73 Zob. szerzej, Alternatywa dla prawicowych kłótni, rozmowa z przewodniczacym SLD Grzegorzem Napieralskim, „Trybuna”, 5 czerwca 2009, s. 2; Satysfakcja ale umiarkowana, rozmowa z Aleksandrem Kwaśniewskim, „Trybuna”, 9 czerwca 2009, s. 2; Patrzcie jesteśmy, rozmowa z Grzegorzem Napieralskim, „Trybuna”, 9 czerwca 2009, s. 2.

${ }_{74} \mathrm{http}: / /$ wiadomosci.onet.pl/2008249,12,item.html. 